DOI: https://doi.org/10.15688/jvolsu4.2016.6.7

UDC 94(47)“1853/1856”(477.75)

Submitted: 25.06 .2016

LBC 63.3(2p.Кры) 521.2

Accepted: 30.08 .2016

\title{
BEYOND THE THEATRE OF MILITARY OPERATIONS: THE MONUMENTS OF THE CRIMEAN WAR IN SIMFEROPOL AND BAKHCHISARAY
}

\author{
Nikolay A. Syedin \\ Taurida Academy of the Crimean Federal University named after V.I. Vernadskiy, \\ Simferopol, Republic of Crimea, Russian Federation
}

\begin{abstract}
The article is devoted to the events that took place on the Crimean peninsula during the Eastern War (1853-1856) beyond the main battle fields. The author describes overall picture of what was happening in the Crimean cities on the background of heroic defense of Sevastopol, names cities which experienced invasion and tells about the consequences of their occupation. The article mainly focuses on Simferopol and Bakhchisaray as the front-line cities that played a significant role in defense of Sevastopol and experienced all the consequences of military actions on the Crimean peninsula. The author names the famous participants of the Crimean War whose lives were closely connected with those cities, and tells about historical monuments related to the events of those years. The aforementioned participants include the famous writers L.N. Tolstoy and N.V. Berg, who spent significant amount of time in those cities during the war. Another personality that draws the author's close attention is N.I. Pirogov, a surgeon whose professional activity on the peninsula at that time was tightly connected with Simferopol. The article also tells about active participants of military operations - generals P.A. Vrevskiy and P.V. Veimarn who lost their lives during the battle at the Chornaya river and were buried in Bakhchisaray. The author believes that knowledge of events that were happening on the entire territory of the Crimean peninsula substantially improves our understanding of the scale of the Crimean War, reveals the drama of the War and its impact on nations, cities and individuals - whether well-known to us or not - and provides additional material for patriotic education. The article describes in detail the work on preservation of memorials of the Crimean War and promotes the attitude of care towards the monuments located all over the Crimean peninsula.
\end{abstract}

Key words: Crimean War, Simferopol, Bakhchisaray, military medicine, military journalism, nurses, historical monuments.

УДК 94(47)“1853/1856”(477.75)

ББК 63.3(2p.Кры)521.2

Дата поступления статьи: 25.06.2016

Дата принятия статьи: 30.08.2016

\section{ТЕАТР НЕБОЕВЫХ ДЕЙСТВИЙ: ПАМЯТНИКИ КРЫМСКОЙ ВОЙНЫ СИМФЕРОПОЛЯ И БАХЧИСАРАЯ}

\author{
Николай Александрович Съедин \\ Таврическая академия Крымского федерального университета им. В.И. Вернадского, \\ г. Симферополь, Республика Крым, Российская Федерация
}

\begin{abstract}
Аннотация. Статья посвящена событиям, которые происходили за пределами поля основных сражений, развернувшихся в период Восточной (Крымской) войны на полуострове. Автор дает общую картину того, что происходило в других городах Крыма в период героической обороны Севастополя. Называются крымские города, подвергшиеся вторжению неприятеля, рассказывается о последствиях их оккупации. Ос-
\end{abstract}


новное внимание уделено Симферополю и Бахчисараю как прифронтовым городам, оказывавшим существенное влияние на ход боевых действий на полуострове и испытавшим все их последствия. Автор приводит фамилии известных участников Крымской войны, чьи судьбы оказались связанными с этими городами. В числе таковых писатели Л.Н. Толстой и Н.В. Берг, которые достаточно долгое время находились в этих городах во время войны. Особое внимание уделено хирургу Н.И. Пирогову, чья деятельность на полуострове в годы войны была тесно связана с Симферополем. Речь идет также об активных участниках боевых действий в Крыму - генералах П.А. Вревском и П.В. Веймарне, погибших в сражении на Черной речке и похороненных в Бахчисарае. Автор полагает, что информирование о событиях, происходивших на всей территории Крыма, существенно расширяет наши представления о масштабах Крымской войны, показывает ее драматизм и роль в судьбах народов, городов и отдельных известных и не известных нам людей, представляет дополнительный материал для патриотического воспитания. В статье подробно говорится о работе по увековечению памяти о событиях Крымской войны, проводимой в Крыму, и о необходимости бережного отношения к памятникам, расположенным на всей территории полуострова.

Ключевые слова: Крымская война, Симферополь, Бахчисарай, военная медицина, военная журналистика, сестры милосердия, памятники истории.

События Крымской войны достаточно подробно и обстоятельно освещены в отечественной и зарубежной научной и художественной литературе. И все же они касаются главным образом боевых действий, связанных прежде всего с обороной Севастополя или предшествующими ей событиями. Памятные места, отражающие эту эпопею, хорошо известны и в России, и за рубежом. Такие названия, как Альма, Балаклава, Инкерман, Черная речка, не говоря уже о самом Севастополе и его оборонительных сооружениях, запечатлены в художественных произведениях, топонимах, стали символами героизма, мужества, военного искусства, а иногда и катастрофических просчетов военного командования. Памятники и памятные знаки, установленные в этих местах, служат хорошей иллюстрацией драматической истории более чем полуторавековой давности. Но столь же драматические (хотя и не столь масштабные) события происходили во многих других местах полуострова. Они, как правило, привлекают к себе гораздо меньше внимания, хотя могут существенно дополнить наши представления о ходе военных действий на полуострове, поскольку были тесно связаны с ними и так или иначе оказывали влияние на их результаты.

Весьма значимое место в Крымской войне заняла Евпатория, вблизи которой произошла высадка союзных войск 14 сентября 1854 г., а неудавшаяся попытка освобождения города русскими войсками под командованием генерала С.А. Хрулева в феврале 1855 г. могла стать одной из последних воз- можностей переломить ход войны в пользу России. Эта неудача была тяжело воспринята императором Николаем I и, возможно, ускорила его кончину.

Серьезным ударом по позициям русских войск в Крыму стал захват союзниками Керчи, обеспечивший им выход в Азовское море. Оккупация англо-франко-турецкими войсками, продолжавшаяся с 24 мая 1855 г. по июнь 1856 г., имела тяжелые последствия и для самого города. К ее окончанию из 20378 человек, проживавших в Керчи в 1854 г., осталось лишь около тысячи горожан и всего 345 уцелевших домов. Город подвергся разграблению и разрушению. Был уничтожен городской сад, здание музея древностей использовалось как пороховой склад, а многие его экспонаты были похищены. Во время оккупации была разрушена Митридатская лестница, разграблены скифские курганы, а некоторые из обнаруженных там археологических находок стали экспонатами Британского музея [6, с. 166]. Обстрелам и грабежам подверглись многие другие приморские города и населенные пункты Крыма. Не избежали этой участи и некоторые дворянские имения на побережье, куда союзники наведывались в поисках провианта и трофеев.

В этом отношении Симферополь и Бахчисарай стоят несколько особняком. Ввиду своего географического положения в глубине Крыма они были относительно удалены от морских коммуникаций, интересовавших союзников в первую очередь. Поэтому эти города не подверглись нападению и обстрелам противника. Но это не умаляет их роли в со- 
бытиях того периода. Она определялась прежде всего тем, что здесь находились жизненно важные центры управления войсками и гражданской жизнью полуострова. Под Бахчисараем были размещены основные силы русской армии, которые должны были воспрепятствовать продвижению войск союзников в континентальную Россию. Здесь проходили военную службу некоторые участники Крымской войны, ставшие впоследствии ее летописцами. В частности, некоторое время в Бахчисарае находился историк, поэт Н.В. Берг, служивший переводчиком в штабе главнокомандующего и выступивший в роли военного корреспондента. Он одним из первых в отечественной литературе предпринял попытку осмыслить события Крымской войны [3, с. 144]. Его заметки составили впоследствии два тома книги «Записки об осаде Севастополя», которая была издана в 1858 году. Отдельная глава этой книги была посвящена Бахчисараю, а еще до ее издания отрывок из книги под названием «Бахчисарай» был опубликован в журнале «Библиотека для чтения» в 1857 году. Эти публикации, а также «Севастопольский альбом» с 37 рисунками принесли автору широкую известность.

Но еще большую славу принесли заметки о Крымской войне другому участнику обороны Севастополя - Льву Николаевичу Толстому. Его участие в Крымской войне, на которую он вызвался добровольцем, связано также и с Симферополем. Здесь, в деревне Эски-Орда, будущий писатель провел в составе четырнадцатой артиллерийской бригады два месяца, о чем напоминает памятник, установленный у трассы Симферополь - Алушта. Этот период был, несомненно, важен для понимания писателем всего, что происходило в Крыму, и формирования позиции Льва Николаевича Толстого в отношении войны, которая потом раскрылась в его «Севастопольских рассказах». О его пребывании в Симферополе, куда он приезжал в свободное от службы время, напоминают улица города, носящая имя писателя, и мемориальная доска, установленная на доме, где он останавливался. Сведения об этом периоде дополняют наши представления не только о самом писателе, трансформации его взглядов, но и дают сведения о том, чем жили прифронтовые города.
Казалось, что здесь текла обычная жизнь и офицеры приезжали узнать последние новости, на отдых и за развлечениями [2, с. 140]. Но война изменила облик этих городов. Особенно это ощущалось в Симферополе, насчитывавшем накануне войны около 15000 жителей. С началом войны численность населения значительно выросла. Здесь находилась гражданская администрация полуострова, сюда были эвакуированы люди, документы и архивы из оккупированных приморских городов. Симферополь и Бахчисарай были чрезвычайно важными звеньями в маршрутах, по которым осуществлялось снабжение русской армии. Но, пожалуй, главная роль этих городов заключалась в том, что они стали своеобразными военными лазаретами для солдат и офицеров, получивших ранения в ходе боевых действий.

Первые раненые были доставлены сюда уже с полей Альминского сражения. Впоследствии поступление раненых превратилось в гигантский конвейер. Вот как описывает дорогу из Севастополя в Бахчисарай Николай Иванович Пирогов, прибывший в Крым по просьбе великой княгини Елены Павловны для организации лечения раненых: «Вся дорога от Бахчисарая на протяжении 30 верст была загромождена транспортами раненых, орудий и фуража. Дождь лил как из ведра, больные и между ними ампутированные лежали по двое и по трое на подводе, стонали и дрожали от сырости, и люди и животные едва двигались в грязи по колено; падаль валялась на каждом шагу; слышались в тоже время и вопли раненых и карканье хищных птиц, целыми стаями слетевшими на добычу, и крики измученных погонщиков, и отдаленный гул севастопольских пушек...» [9, с. 26]. Часть раненых оставалась в Бахчисарае, но большая поступала в Симферополь. К началу января 1855 г. здесь лечилось 4711 человек, а уже к апрелю 166 офицеров и 6845 нижних чинов. Под госпитали и лазареты было занято 72 казенных и частных дома, в том числе губернские присутственные места, губернаторский дом, гимназия, уездное училище, дворянское собрание, казенная палата, богоугодное заведение и другие здания [8]. Многие состоятельные жители Симферополя предоставляли свои дома и загородные имения для лечения раненых. Так, 
в частности, под госпиталь было отдано имение Давыдовых в Саблах, получившее известность благодаря тому, что в разные годы здесь останавливались очень известные в России люди. О том, что в годы войны в этом здании располагался госпиталь, свидетельствует мемориальная доска. Такие же мемориальные доски установлены на многих других сооружениях Симферополя, где размещались раненые.

Тем не менее больничных мест в городе было явно мало. Не спасало и то, что часть раненых эвакуировалась дальше на материк. По описанию французских пленных, которых отправляли из Симферополя через Перекоп в Херсон и Одессу, «все города, деревни, даже хутора превращены в госпитали» [1, с. 136]. Но положение Симферополя, ставшего, по сути, и прифронтовым городом, где находилось огромное число военных и беженцев, и перевалочной базой, через которую шло снабжение войск, и полевым госпиталем под открытым небом, и остававшимся при этом административным центром со всеми присущими ему чертами, было, пожалуй, наиболее сложным. В книге А.И. Маркевича «Таврическая губерния во время Крымской войны по архивным материалам» приводится следующее описание города очевидцем: «Раздирающие душу стоны больных и раненых, погребальные марши и заунывный стон колоколов, звуки бешеных вальсов и полек, безумных кадрилей и глубоких воплей несчастных, потерявших близких сердцу людей, все каждую секунду сливалось в один чудовищный гул. Люди, обозы и гробы массами толпились по улицам. Симферополь в это время с пришлым населением и войсками имел более ста тысяч жителей и был похож на страшный громадный водоворот, в котором вертелись с напряжением всех сил люди и животные, перегоняя и давя друг друга между гробами покойников и обозами промышленников» [4, c. 204]. Помощь раненым стала главным предназначением города в этот период. Большой вклад в организацию их лечения в Симферополе внес Николай Иванович Пирогов. Здесь он находился около четырех месяцев из 282 дней, которые он провел на полуострове в период Крымской войны, проживая в гостинице «Золотой Якорь» по ул. Салгирной. О его пребывании в Симферополе свидетельствует памятная доска, установленная на здании военного госпиталя, где Пирогов проводил операции. Помимо этого он осматривал раненых, находившихся в других местах, перемещаясь по всему городу. В его письмах к жене говорится, что таких осмотров он проводил от восьмисот до тысячи в день. Одновременно Николай Иванович инспектировал состояние помещений и условия, в которых находились больные. Вот как описывает он увиденное в Симферополе в своих воспоминаниях: «Несчастные, наполнявшие дома, были лишены почти всякого ухода. Многие валялись на полу, безо всякого разбора и присмотра. Недоставало ни умов, ни рук, чтобы хоть немного привести весь этот невообразимый хаос в известность и порядок» [5, с. 199].

Н.И. Пирогов предложил ряд мер, которые могли существенно улучшить положение больных. Он инициировал размещение раненых в специально построенных летних бараках, внедрил новые методы лечения, впоследствии широко применявшиеся в военной хирургии. При этом он находил время и для консультаций жителей города. Одним из его пациентов стал Д.И. Менделеев, учительствовавший в это время в Симферополе. Знаменитый хирург сам читал лекции врачам.

Надо сказать, что в городе ощущалась огромная нехватка медперсонала. Поэтому для лечения раненых сюда были мобилизованы врачи со всей Таврической губернии. Приезжали медики и из других уголков России и даже из-за рубежа. По утверждению А.И. Маркевича, в Симферополе работали врачи из США и Германии [4, с. 71].

Особую роль сыграла деятельность сестер милосердия, прибывших в Крым по инициативе великой княгини Елены Павловны. Первое отделение из 28 сестер под управлением Александры Павловны Стахович Пирогов, учитывая чрезвычайное госпитальное положение в губернском центре, распорядился оставить (хотя это было не согласовано с великой княгиней) в Симферополе. В дальнейшем Николай Иванович направлял вновь прибывших сестер милосердия не только в Севастополь, но и в Карасубазар, и в Бахчисарай, где находилось множество раненых. Им приходилось работать в невероятно сложных 
условиях. Ухаживая за больными тифом, некоторые из сестер милосердия заболевали сами и даже умирали от болезней. Но ценой своей жизни они спасли жизни тысяч раненых.

Несмотря на титанические усилия медиков, смертность среди раненых была чрезвычайно высока. Их тела хоронили в братских могилах на воинских кладбищах Симферополя и Бахчисарая. Некоторые из этих кладбищ сохранились до наших дней. Одно из них расположено в Симферополе в Петровской балке, где было захоронено свыше 36000 участников обороны Севастополя, погибших от ран и болезней. Здесь в 60-х гг. XIX столетия была построена часовня, на главном фасаде которой укреплена доска с надписью: «Построено в 1868-1869 годах по всемилостивейшему благоволению и по повелению Государя императора Александра Николаевича над местом погребения воинов Крымской армии, павших за Веру, Царя и Отечество в 18541855 годах». Рядом расположен первый в Симферополе памятник, сооруженный на пожертвования горожан, с надписью «От граждан Симферополя на месте погребения воинов Крымской армии».

Несколько братских могил, в которых покоятся защитники Севастополя, расположено в городе Бахчисарае. Одна из них находится на ул. Симферопольской. Здесь захоронены воины, умершие от ран во время транспортировки из Севастополя в Симферополь и другие города. В 1865 г. над могилой был насыпан курган, а в 1896 г. установлен восьмиконечный православный крест.

Еще одним памятником в Бахчисарае, связанным с событиями Крымской войны, является часовня на православном кладбище в старой части города. Рядом с часовней покоится прах 4000 защитников Севастополя, умерших от ран в бахчисарайских госпиталях в период войны. Часовня сооружена к 40-й годовщине начала героической обороны Севастополя по инициативе жителей Бахчисарая.

Памятники погибшим воинам находятся на территории Успенского монастыря в ущелье Мариам-Дере под Бахчисараем, где в годы Крымской войны располагался военный госпиталь, в котором также работали сестры милосердия Крестовоздвиженской общины. Сре- ди могил погибших на поле боя и умерших от ран в госпитале здесь есть те, которые принадлежали людям, сыгравшим заметную роль в событиях тех лет. В одной из них покоится прах Павла Александровича Вревского, погибшего в сражении у Черной речки. О генерале Вревском известный исследователь Крымской войны Е.В. Тарле пишет как об одном «из тех блестящих придворных генералов, которые без всяких усилий и заслуг сделали легкую военную карьеру в залах Зимнего дворца» [7, с. 467]. Это не вполне справедливо, так как на самом деле П.А. Вревский принимал участие во многих боевых действиях. Окончив в 1828 г. Школу гвардейских подпрапорщиков и кавалерийских юнкеров, он сразу же направился в театр боевых действий в Русско-турецкой войне. Был контужен под Варной, эвакуирован в Одессу и вышел в отставку. Затем вернулся на службу, участвовал в подавлении Польского восстания, принимал участие в военных экспедициях на Кавказе. Несколько нелестную характеристику от Е.В. Тарле генерал Вревский, по-видимому, получил как один из инициаторов неудачного для русской армии сражения на Черной речке. В Крым генерал-адъютант Павел Александрович Вревский был направлен с тем, чтобы убедить главнокомандующего М.Д. Горчакова в необходимости новой наступательной операции. И хотя его роль при командующем выглядела весьма неоднозначно, но тот же Тарле отмечает, что «он не был карьеристом чистой воды... сам был убежден в необходимости дать генеральное сражение. И когда он увидел, к чему привела его непростительная настойчивость, - он заплатил жизнью за свою тяжкую ошибку» [7, с. 467]. Гибель П.А. Вревского в книге Тарле описана в героических тонах: «он побывал в самых опасных местах боя. Осколком ядра убило под ним лошадь, и он упал на землю. Сейчас же пересев на другую, он тихим шагом поехал к Горчакову, который стал убеждать его хоть на время удалиться и оправиться от ушибов. Вревский остался. Другое ядро сорвало с него фуражку движением воздуха и контузило его. Вревский не трогался с места. Третье ядро раздробило ему голову» [7, с. 480].

Здесь же, на территории Успенского монастыря, похоронен и генерал Петр Владими- 
рович Веймарн, также погибший в сражении на Черной речке. В период военных действий под Севастополем он занимал должность начальника штаба третьего пехотного корпуса. В войсках П.В. Веймарн оставил о себе память как человек, заботящийся о своих солдатах и стремящийся всячески облегчить их положение. Судя по всему, он тоже понимал всю безнадежность и неподготовленность наступательных действий русской армии [7, c. 479] и пытался убедить командование отложить наступление, что нашло отражение даже в широко известных стихах об этом сражении, приписываемых Л.Н. Толстому. Но вместе с командующим группой войск генералом Н.А. Реадом он не осмелился не выполнить приказ командующего армией М.Д. Горчакова о наступлении и разделил участь 10000 солдат, офицеров и генералов, погибших в сражении. Памятник Петру Владимировичу Веймарну в Успенском монастыре был поставлен его сослуживцами, уважавшими и любившими своего генерала. А рядом с захоронением в 1875 г. на пожертвования генерала Г.И. Перовского был сооружен храм в честь святого воителя Георгия Победоносца как память всем воинам, сражавшимся за Отчизну.

Сохранение и популяризация этих и других памятников, установленных в ознаменование событий Крымской войны в Симферополе и Бахчисарае, не только дань памяти ушедшим поколениям. Они существенно расширяют наши представления о масштабах Крымской войны, показывают весь ее драматизм и роль в судьбах народов, городов и отдельных известных и не известных нам людей.

\section{СПИСОК ЛИТЕРАТУРЫ}

1. Крымская Илиада. Крымская (Восточная) война 1853-1856 годов глазами современников: литература, архивы, пресса / Л. А. Орехова, В. В. Орехов, Д. К. Первых, Д. В. Орехов. - Симферополь : Симферопольская городская типография, 2010. $480 \mathrm{c}$.

2. Кунцевская, Г. Н. Благословенная Таврида. Крым глазами великих русских писателей / Г. Н. Кунцевская. - Симферополь : Издательство Крым, 2008. $-392 \mathrm{c}$.

3. Маленко, А. Ю. Бахчисарай 1855 года в прозе и поэзии Н. Берга / А. Ю. Маленко // Восточная
(Крымская) война 1853-1856 годов: новые материалы и новое осмысление : материалы Междунар. науч. конф. В 2 т. Т. 1. - Симферополь : Крымский Архив, 2005.

4. Маркевич, А. И. Таврическая губерния во время Крымской войны по архивным материалам / А. И. Маркевич. - Симферополь : Бизнес-Информ, 1994. -268 c.

5. Пирогов, Н. И. Севастопольские письма и воспоминания / Н. И. Пирогов. - М. : Изд-во АН CCCP, 1950.-649 c.

6. Санжаровец, В. Ф. Некоторые вопросы сохранения памяти о Крымской войне в Керчи / В. Ф. Санжаровец // Восточная (Крымская) война 1853-1856 годов: новые материалы и новое осмысление : материалы Междунар. науч. конф. В 2 т. Т. 1. - Симферополь : Крымский Архив, 2005.

7. Тарле, Е. В. Крымская война. В 2 т. Т. 2 /Е. В. Тарле. - 2-е изд. - М. : Изд-во АН СССР, 1950. $653 \mathrm{c}$.

8. Широков, В. А. Симферополь. Улицы рассказывают / В. А. Широков, О. В. Широков. - Симферополь : Таврия, 1983.-129 с.

9. Эрлихман, В. Крымская война доктора Пирогова / В. Эрлихман // Историк. - 2016. - № 4 (16). C. 24-29.

\section{REFERENCES}

1. Orekhova L.A., Orekhov V.V., Pervykh D.K., Orekhov D.V. Krymskaya Iliada. Krymskaya (Vostochnaya) voyna 1853-1856 godov glazami sovremennikov: literatura, arkhivy, pressa [Crimean Iliad. The Crimean (Eastern) War of 1853-1856 in the View of Contemporaries: Literature, Archives, Press]. Simferopol, Simferopol City Printing House, 2010. $480 \mathrm{p}$.

2. Kuntsevskaya G.N. Blagoslovennaya Tavrida. Krym glazami velikikh russkikh pisateley [Blessed Taurida. Crimea in the View of the Great Russian Writers]. Simferopol, Izd-vo Krym, 2008. 392 p.

3. MalenkoA.Yu. Bakhchisaray 1855 goda v proze i poezii N. Berga [Bakhchisaray of 1855 in Prose and Poetry of N. Berg]. Vostochnaya (Krymskaya) voyna 1853-1856 godov: novye materialy i novoe osmyslenie: materialy Mezhdunarodnoy nauchnoy konferentsii. V2 t. T. 1 [Eastern (Crimean) War of 18531856: New Materials and New Understanding. Materials of the International Scientific Conference. In 2 vols. Vol. 1]. Simferopol, Krymskiy Arkhiv Publ., 2005.

4. Markevich A.I. Tavricheskaya guberniya vo vremya Krymskoy voyny po arkhivnym materialam [Taurida Province During the Crimean War Based on Archive Materials]. Simferopol, Biznes-Inform Publ., $1994.268 \mathrm{p}$. 
5. Pirogov N.I. Sevastopolskie pisma i vospominaniya [Sevastopol Letters and Memories]. Moscow, Izd-vo AN SSSR, 1950. 649 p.

6. Sanzharovets V.F. Nekotorye voprosy sokhraneniya pamyati o Krymskoy voyne v Kerchi [Some Questions of Preserving the Memories of the Crimean War in Kerch]. Vostochnaya (Krymskaya) voyna 1853-1856 godov: novye materialy i novoe osmyslenie: materialy Mezhdunarodnoy nauchnoy konferentsii. V2 t. T. 1 [Eastern (Crimean) War of 18531856: New Materials and New Understanding. Materials of the International Scientific Conference. In 2 vols. Vol. 1]. Simferopol, Krymskiy Arkhiv Publ., 2005.

7. Tarle E.V. Krymskaya voyna. V 2 t. T. 2 [The Crimean War. In 2 vols. Vol. 2]. Moscow, Izd-vo AN SSSR, 1950. $653 \mathrm{p}$.

8. Shirokov V.A., Shirokov O.V. Simferopol. Ulitsy rasskazyvayut [Simferopol. Streets Talk]. Simferopol, Tavriya Publ., 1983. 129 p.

9. Erlikhman V. Krymskaya voyna doktora Pirogova [Doctor Pirogov's Crimean War]. Istorik, 2016, no. 4 (16), pp. 24-29.

\section{Information About the Author}

Nikolay A. Syedin, Candidate of Sciences (Politics), Associate Professor, Department of Political Sciences and International Relations, Taurida Academy of the Crimean Federal University named after V.I. Vernadskiy, Prosp. akademika Vernadskogo, 4, 295007 Simferopol, Republic of Crimea, Russian Federation, nikolai.sedin@mail.ru.

\section{Информация об авторе}

Николай Александрович Съедин, кандидат политических наук, доцент кафедры политических наук и международных отношений, Таврическая академия Крымского федерального университета им. В.И. Вернадского, просп. академика Вернадского, 4, 295007 г. Симферополь, Республика Крым, Российская Федерация, nikolai.sedin@mail.ru. 